\title{
SOCIAL INTERACTIONS BETWEEN JAVANESE ETHIC GROUP AND BALINESE ETHNIC GROUP
}

\author{
Ayu Reza Ningrum \\ Master of Social Science Education, University of Lampung \\ Sudjarwo \\ Faculty of Teacher Training and Education, University of Lampung \\ Pargito \\ Faculty of Teacher Training and Education, University of Lampung
}

\begin{abstract}
Abstrak
Tujuan dari penelitian ini adalah untuk menyelidiki interaksi sosial antara dua kelompok etnis Jawa dan Bali di Bawang Tirto Mulyo dan Kahuripan Dalam, khususnya dalam bentuk kerjasama, asimilasi, akulturasi, dan akomodasi dalam dua level, yaitu interaksi antara individu dan interaksi antar kelompok. Penelitian ini menggunakan metode deskriptif kualitatif. Data dikumpulkan melalui observasi, wawancara, dan dokumentasi yang diperoleh dari sumber utama yaitu orang-orang yang tinggal di Bawang Tirto Mulyo dan Kahuripan Dalam. Hasil penelitian menunjukkan bahwa (1) interaksi antara individu Jawa dan Bali berjalan harmonis ditandai dengan toleransi dan saling menghormati dan tidak ada diskriminasi etnis ditemukan dalam bergaul, (2) interaksi antara kelompok berjalan dalam bentuk kerjasama, asimilasi, akulturasi, dan akomodasi. Kedua kelompok etnis memahami bahasa masing-masing meskipun orang Jawa memahami bahasa Bali secara pasif sementara mayoritas orang Bali dapat secara aktif berkomunikasi menggunakan bahasa Jawa. Berdasarkan hasil penelitian, dapat disimpulkan bahwa toleransi dan saling menghormati antara dua kelompok etnis menyebabkan interaksi sosial yang asosiatif.
\end{abstract}

Kata Kunci: Interaksi Sosial, Suku Jawa, Suku Bali

\begin{abstract}
The objective of the resrach is to investigate social interaction between two ethnic groups of Javanese and Balinese in Bawang Tirto Mulyo and Kahuripan Dalam, particularly in the forms of cooperation, assimilation, acculturation, and accommodation in two levels, i.e., the interaction between individuals and the interaction between groups. This research used qualitative descriptive method. The data were collected through observation, interview, and documentation obtained from the primary source that is the people who live in Bawang Tirto Mulyo and Kahuripan Dalam. The results showed that (1) the interaction between individuals of Javanese and Balinese runs harmoniously characterized by tolerance and mutual respect and no ethnic discrimination was found in associating, (2) the interaction between groups runs in the form of cooperation, assimilation, acculturation, and accommodation. The two ethnic groups understand each other's language although the Javanese understand Balinese language passively while the majority of Balinese can actively communicate using Javanese language. Based on the results of the research, it can be conluded that the tolerance and mutual respect between the two ethnic groups lead asociative social interaction.
\end{abstract}

Keywords: Social Interactions, Javanese Ethic Group, Balinese Ethnic Group

\section{INTRODUCTION}

Indonesia is an archipelagic country comprising of varieties of different religions, ethnic groups, and cultural groups. The social diversities could initially become factors that unified the country so that Indonesia could achieve its independence, but now the difference is actually a source of disaster. History has noted that ethnic conflicts in some 
parts of Indonesia, such as what had happened in Ambon, Sampit, Poso and Lampung, were a sadening civil war since they comptete to control natural resources, political resources, and economic resources. Inter-ethnic conflicts are usually known as tribal wars, involving various forms of violence and warfare that touch human values. Interethnic conflict has also occurred in the area of Lampung. Example of phenomenal inter-ethnic conflict in Lampung includes what had happened in south Lampung District on October 27, 2012 until October 29, 2012 which attract national attention in which this conflict involved Lampungese Ethnic (indinegenous indigenous / Moslem majority) and Balinese Ethnic (immigrant / Hindu majority ) triggered by a trivial issue that is not resolved legally by the prevailing customs.

Lampung is located in a southernmost province on the island of Sumatra. Geographically, Lampung is the gateway between Java and Sumatera Island. Demographically, Lampung represents Indonesian multicultural miniature. According to BPS (Center of Statistic Board) 2010 [17], the population amounted to 7,634,005 inhabitants (2012). Judging from the social culture, various ethnic groups live in Lampung, besides the origin ethnic (Lampung ethnic), there are various ethnic groups such as Semendo, Bali, Lombok, Java,
Padang, Batak, Sunda, Madura, Bugis, Banten, Palembang, Aceh, Makassar, foreign ethnic (Chinene and Arabic). The ethnic diversities of Lampung was also contributed by the colonization program in 1905 and transmigration program after Indonesia declared its independence.

Lampung, especially Tulang Bawang Regency, is a home for varieties of ethnic groups such as Indigenous Ethnic of Menggala, Javanese, Balinese, Batakese, Semendo, Sundanese and many more. The social life in Tulang Bawang is relatively well established where every ethnic group can interact socially well. The differeing social background like religion and other cultural differences are not regarded as a barrier to socially mingle in dailyn life. Life is peaceful although there are minor conflicts between individuals or groups of different ethnics, the conflics can still be resolved in peaceful manner. Bawang Tirto Mulyo and Kahuripan Dalam are among the villages registered in Tulang Bawang District. Administratively, the two villages are registered in different districts, but geographically the two villages are neighbouring each other. Bawang Tirto Mulyo village (Javanese majority) and Kahuripan Dalam village (Balinese ethnic majority) are immigrant ethnic. The differences between these two ethnic groups are very clear in terms of religion and culture. Balinese ethnic is known for having good work ethic so that 
economically Balinese are usually classified as a well-to-do family. The Javanese are also known for their friendly and tenacious ethnic. Most of the two ethnic groups have large field because the environmental conditions of Tulang Bawang Regency are suitable for field, such as rubber, palm and cassava.

However, inter-ethnic conflicts have also occurred in Desa Bawang Tirto Mulyo and Kahuripan Dalam, it happened between Javanese and Balinese. The conflic started in the early 1990s in which Balinese ethic gorup began to occupy and formed a settlement in the area which is now called Kahuripan Village. Initially, most of the Balinese ethnic group bought the land in the form of vacant land from some Lampungese ethnic group around Kahuripan Dalam (by this time) and they began to build a house as a shelter. In fact, the majority of land area that ethnic Balinese people occupy has been possessed by several Javanese Ethnic who lived in the Bawang Tirto Mulyo. Feeling unacceptable, Javanese ethnic who feel that their rights have been taken by others, then they are involved in arguments even almost fistfight each other. Some of the Javanese ethnic had once bought the land from the Lampungese ethnic group, however, the Lampung ethnic group offered the land to Balinese ethnic. Finally, they try to solve the problem peacefully so that they find the root of the problem. They realize that what is wrong is the first party who sell the land. Most indigenous people, Lampung ethnic group, from the past until quite recently, feel that where there is an empty land, the land is definitely theirs, so they feel free to sell and buy the land. The conflict made the people of both villages, Bawang Tirto Mulyo and Kahuripan Dalam in high tension. Refering to this fact, the researchers wanted to know how the interaction between Javanese in Bawang Tirto Mulyo and Balinese in Kahuripan Dalam Village is conducted.

\section{RESEARCH METHOD}

The research approach used in this research is qualitative approach. Qualitative research according to Bodgan and Taylor in Sujarweni (2014) is one of the research procedures that produces descriptive data in the form of speech or writing and the behavior of the observed participants. Ethnography apprioach is used in this research. According to Bungin (2012) ethnographic research is a systematic depiction and analysis of a culture group, society or ethnicity collected from the field data in the same period of time. The inofrmants serving as data elicitations, in this study, are religious leaders (Javanese ethnic group and Balinese ethnic group), indigenous figures (Balinese ethnic), community leaders (head of village), head of environment, and village pioneers. 
Snowball techniques is used to determine who will become the data resources. The data were also collected through participant observation, closed interview, and documentation. The data were then analyzed using Miles and Hubermen (1984) in Sugiyono (2013). The analysis suggests that the activity in qualitative data analysis is done interactively and continuously to gain complete data. One of the indication that the collected data were saturaed is that there is no new information retrived anymore.

\section{RESULTS AND DISCUSSIONS}

Human being is a social creature in which he/she cannot live alone and he/she needs others to survive. In everyday life, human beings always make contacts with others either individually or with groups and these relationships will form a social interaction. Social interaction can be defined as dynamic social relationships. In the process of interaction, there is a symbol which is defined as something whose value or meaning is given to it by those who use it. According to Soekanto (2015) social interactions are dynamic social relationships concerning the relationships between individuals, between human groups, and between individuals and between groups. Interaction is the starting point of a social event. The requirement of social interaction is social contact and communication. Positive social contact will lead to a collaboration, whereas negative social contact leads to a conflict or even no social contact. Communication is the second key to the creation of such interactions. Communication is a manifestation that someone gives interpretation to others (in the form of speech, body movements or attitudes), and what kind of feelings the person wants to convey. The person concerned then reacts to the feelings to be conveyed. By having communication, human bing can derive the attitudes and feelings of a particluar group or others. The attitude and feelings of a partricular group are used to determine what kind of reaction will a certain group gives.

In social life, we always hold an interaction as the fulfillment of life of human as social beings. The results of interactions between individuals and between groups will always be encountered, whether in the form of cooperation, assimilation, acculturation and accommodation, especially in a multicultural community. Indonesia is a pluralistic nation consisting of many different religions and ethnicities. Almost every ethnic group has different languages, cultures, and customs that characterize and distinguish its identity from others. According to Manan (1989), there are more than 200 kinds of ethnic groups in Indonesia and they will be more 
if they are associated with the religion they embrace. These differing peoples live in more than 13,000 islands in the archipelago. One of the most driving factors for the spread of these various ethnic groups was the transmigration starting in 1905, which was popularly called colonialization. According to Sudjarwo (2005), although the name changes, there is an uncahned concept which refers to human movement.

Transmigration is a unique program and it particluarly happens in Indonesia. In this program, the government actively involves in moving large numbers of people, crossing oceans, and this program has been conducted for long time. Transmigration which is widely followed by residents from Java Island is a general transmigration held by the government. Transmigration was firstly situated in Lampung, Bagelan Village which is recently registered into Pesawaran District. The people were spread almost everywhere in Lampung, one of them was in Bawang Tirto Mulyo in 1979. The arrival of the people from Java occurred in 1979 in Bawang Tirto Mulyo, Tulang Bawang district. They followed the transmigration program because the givernment needed to reduce the population density of the island of Java apart from increasing a better life in the new place. Other reason was that they life was far from minimum standar of life, they only rely on land which was possed by other landlord so that it will not be sufficeint to support the family and and to meet the daily needs. In 1990s the people from Bali and the people from Cental Lampung of Balinese ethnic came in the village of Kahuripan Dalam. The type of transmigration program followed by Balinese ethnic originated from Bali Island and Middle Lampung Regency was called spontaneous transmigration program because this program was selfsuported and done in its own business to find chances of life.

Transmigration or human movement will affect the movement of language, culture and customs. In running the social process in society, there will be cooperation among individuals with each other to be able to achieve the desired goals. This requires good communication in order to understand each other's intentions of cooperation. A good cooperation will occur if we can respect each other's differences among the ethnic groups in Bawang Tirto Mulyo Village and Kahuripan Dalam Village, without offending and harming each other. People of Bawang Tirto Mulyo and Kahuripan in different ethnic groups live side by side harmoniously having mutual respect for the differences that exist between them. The key to live a good social life is to be able to interact well. It is sometimes difficult when a society has to mingle with other people of different ethnicity because there are many 
differences that they face between them.

It is an unavoidable fact that Indonesian society consists of many different social, ethnics, cultural groups, religious adherents, and political aspirations so that Indonesian society is popularly called multicultural society. This diversity, acknowledged or not, will lead to disintegration if there no sense of tolerance in social life. Ma'hady (2004) states that the the reality of "multicultural" is faced with an urgent need to reconstruct the "Indonesian national culture" or "culture of nation" which can be an "integrating force" that can bind all the ethnic and cultural diversity. The basic principles of multiculturalism recognize and appreciate the diversity of community groups such as ethnicity, race, culture, gender, social strata, religion, differences of interests, desires, vision, beliefs and traditions that will greatly assist the realization of conducive and very promising behavioral changes amid the existence of life in a pluralistic society and nation. The multicultural approach is actually based on awareness to appreciate and respect each other. Based on issues aformentioned, the resrachers explain the form of social interaction found in the field covering interaction between individual and intergroup seen from the form of cooperation, assimilation, acculturation and accommodation.

\section{Interaction between Individuals:}

\section{Cooperation.}

The forms and patterns of cooperation can be found in all human groups such as habits and attitudes beginning in childhood in family life or kinship groups. This form of cooperation develops when people can be mobilized to achieve a common goal and there must be awareness that the goal in the future has benefits for all. Cooperation will always be encountered during the course of the life process. As the findings in the field of inter-ethnic cooperation between Java and Bali in Bawang Tirto Mulyo and Kahuripan Dalam is a form of contract cooperation. Contract cooperation is usually encountered in terms of work contract. The majority of the people of Bali love to use the services of the Java community to take care of his garden. Balinese people assume that their favorite reason to use the services of the Javanese community compared to other ethnicity is because they have a diligent, submissive, hardwrker, and patient in nature. Thus, they assume that Javanese people are more apt to be employed as laborers in their own gardens. It turns out that such an assumption is also expressed in the results of research conducted by Alifirdaus (2014) revealing that the ethnic Padang (Minang) considers that the 
Javanese are only attractive to laborers rather than business partners because of their being too patient and slow in moving. Other form of cooperation is spontaneous cooperation. This happens like in the case when they hear that there are neighbors who have been struck by a hardship like sickness case or death matter. They will pay a visit and offer helps in the form of either material or spiritual. When they hear the news of death, they come straight to show their mourning. Pluralism is understood as a collection of various social elements unifying in the same environment, the elements have oppotunities to be different so that there is a difference. Differences are not made for as factor fopr conflicting, but they shoud be understood that the difference is a divine product that must be realized and grateful. Differences are seen as ways of understanding oneself on the basis of pure humanity, not on the basis of equality or ethnic differences and beliefs. Spontaneity of helping each other is basically the essence of tolerance and plurality.

\section{Assimilation}

In every life, we will find a process of assimilation. In the process of assimilation, they identify themselves with the group's interests and goals. When two groups of people hold assimilation, the boundaries between the groups will disappear and the two unite into one group. Good relationship that exists between the different individuals also gives rise to an assimilation. Assimilation may indicate the existence of interests or goals to be achieved together through a harmonious life in the community. As social beings, humans play a social role. According to Santosa (2013), the reconstruction of social roles is an aspect of the ongoing negotiation of the social definition in which the individual is engaged and through which they establish an order and stability. An order and stability can be achieved through such an effort between the two villages by visiting each other when Balinese Ethnic group celebrate Galungan Day, Javanese visit and share food. On the other hand, when Javanese celebrate Idul Fitri Day (a clelbration after fasting month of Ramadhan), this moment is also used as a time for interethnic friendship. In celebrating certain holidays, they will use these moments for share food. Usually a special tradition like this is done by people who live adjacent to Bawang Tirto Mulyo and Kahuripan Dalam.

\section{Acculturation}

According to Soekanto (2015), acculturation is a social process that arises when a group of people with their culture is exposed to elements of foreign culture. Acculturation is the result of a 
mixture of both cultures occuring in a long time. The element of foreign culture is equally accepted by the interacting group, and they are processed without losing the original cultural personality as the recipient. The form of interaction that refers to the acculturation between Java and Bali in Bawang Tirto Mulyo and Kahuripan Dalam encompasses the personal issues like praying together. According to the informants who is Balinese Ethnic, they are occasionally invited by neighbors (Javanese Ethnic) to come to the celebration event. Kenduri is one the traditional events aiming at praying to God. This is usually done by small family unit and kenduri is usually conducted by Javanese Ethnic. Kenduri is usually performed in relation to birth or death. Initially, researchers thought there would not be such an interaction so the researchers did not ask about the mater. It fact, there are several interactions as told by inoformans. There are some Javanese people who invite neighbors or friends to attend the event kenduri. The fact also show that the invitation is not only addressed to the same ethnic (javanese) but it is also addressed to different ethnic (Balinese ethnic) to attend the event. Sometimes in Bawang Tirto Mulyo invite Balinese friends in Kahuripan Dalam village to attend a gathering event (prayer Javanese ethnic communities) and it does not happen to the Balinese ethnic community in Kahuripan Dalam. However, if Balinese are invited to attend kenduri in Bawang Tirto, they attend the kenduri nd pray based on their own belief. According to them, attending the session is a form of mutual respect and it does not matter. It is an interesting case because it can be one of the unique forms of acculturation.

Another form of unique culture as a result of acculturation through this interaction is that the custom of "nyumbang" (giving money to a family who is holding a special session like birth, death, or wedding). Nyumbang is a tradition aiming to help and ease the host's burden. Nyumbang may happen in the case of special events such as marriage, birth, death, and other misfortune cases. For the people of Bawang Tirto Mulyo and Kahuripan Dalam, if they receive a marriage invitation or when they know that their neighbor who delivers baby, then they will come to fulfill the invitation. As for birth case, if they know that Balinese neighbor or friend give birth, without an invitation, they will come to visit and usually they will bring souvenirs such as money, baby's needs (powder, bath soap, clothes etc). The same thing happened to the Balinese community of Kahuripan Dalam. They will attend wedding invitations in the village of Bawang Tirto Mulyo. Without being asked or invited, they will visit they neighbor or friends 
who are holding the session. They will also bring the souvenirs as they do to the Javanese ethnic community in Bawang Tirto Mulyo. Such social action shows the sensitivity of interethnic communities in Bawang Tirto Mulyo and Kahuripan Dalam. The culture is done regardless of ethnic differences. According to Santosa (2013) such cultures form a kinship relationship among the actors, kinship relations are not biological in nature, but they are a number of social relationships mapped over biological relationships. Such social action shows the sensitivity of interethnic communities in Bawang Tirto Mulyo and Kahuripan Dalam.

\section{Accommodation}

Accommodation that refers to a particular condition means that there is a balance (equilibrium) in the interaction between individuals or groups of people in relation to social norms and social values prevailing in society. As a process, accommodation refers to human's efforts to reduce a conflict, it refers to a number of efforts aiming to achieve stability (2015). The finding of the research shows that one of the simplest forms of accommodation is in the form of tolerance. The people of Bawang Tirto Mulyo and Kahuripan Dalam develop mutual understanding and tolerance seen from their daily life in which they mingle without seeing their ethnic diversities. Based on the information from the respected figure, it is true that living in society, one may not discriminate based on the his/her social background (culture and belief). He further says that being good or bad is not determined by his/her social background. The condition shows that the two people of differing ethnic group can manage their existence very well. This is in line with Soemardjan (1964), that there is no society if there is no social interaction. Social interaction is the key to all social life because without social interaction, there can be no togetherness in life.

\section{Interaction between Groups}

Viewed from every aspect, Indonesian society is a pluralistic society. This is an indisputable phenomenon because Indonesia consists of varieties of different tribes, races, religions, and groups but it remains one as it is stated in the slogan "Unity in Diversity". This terminology implies the meaning to the social reality that occurs to the people of this nation. On the one hand there should be awareness of the differences and on the other hand there is a need to be unity and union. The form of social reality is social contact which is the product of interpersonal unity that will form groups according to their own similarity like language, culture, religion and etc. Individuals in a particular area will find themselves their groups in which they have to join. These groups can also 
be depicted in Bawang Tirto Mulyo which is predominantly inhabited by Javanese ethnic who was established through transmigration program in 1979 and Kahuripan Dalam which is predominantly by the majority of Balinese ethnic groups established through self-funded transmigration program. Living side by side with other ethnicity makes them learn from each other, appreciate and understand their own culture and the must learn to cooperate well as social beings.

\section{Cooperation}

Cooperation is a form of social interaction in which there is a joint effort between a person or a group to achieve a common goal. This form of interaction is usually born because there are similarities of interests, goals and views. The form of cooperation among ethnic groups in Bawang Tirto Mulyo and Kahuripan Dalam is realized in terms of mutual cooperation when they parade "ogoh-ogoh festival". The ogoh-ogoh parade was conducted after the Balinese ethnic community performed the Nyepi worship (Day of Silence). The parade of ogoh-ogoh means that they drive out the evil that influences around them. The ogoh-ogoh parade features a large statue raised and paraded by the crowd. The ogoh-ogoh parade was competed in district level so that all Balinese ethnic gather in the place. It takes a lot of energy to lift the ogoh-ogoh. Usually, ogoh-ogoh is raised by not only ethnic Balinese but also by Javanese ethnic from Bawang Tirto Mulyo. This parade usually causes traffic jam and it attract public attention. When ogoh-ogoh parade was held, all the people took their time to watch as it has become a tradition of citizens to attend the parade. It is a form of acculturation that occurs between individuals and groups. According to Zamroni (1992) the unification of culture or acculturation creates new social ties or strengthens the existing social ties, and it progresses to equilibrium, as it is demonstrated in structural functionalism.

Other findings on cooperation of mutual assistance occurs when people of Javanese ethnic who asked for help to Balinese ethnic to make mosque miniature because Balinese ethnic group is known to have artistic sense. The mosque miniature was later used in the parade of "takbiran" celebrating Idul Fitri Day. This is the case that between the two ethnic groups shows that they would cooperate regardless of ethnic and religious differences. Such form of cooperation, according to Soekanto (2015) is the embodiment of traditional cooperation in a social system.

\author{
Assimilation \\ Humans as social creature show \\ their dependence from individual to
}


other individual because they social creature who like to be in group or to make friends. Living together is a means to meet the needs either physical needs or spiritual needs. It is also to a man or a woman who has reached a certain period of age, he/she will experience the problem. He/she wants to fulfill his/her needs of life by spending their life together with someone who can make his/her life happy so that he/she can share happiness and sadness together. This can be reached through marriage. Marriage according to Santosa (2013) is an internalized form of sexual communion. In Indonesia, different interethnic marriage is common. Assimilation is a social process characterized by different tradition or cultural differences, living for long time and occurring in the same place. There is inter-mingling and cultural unification through a marriage, which is known as amalgamation. Amalgamation is a social process by merging two cultural groups into one, which will eventually produce something new (Assimilation). Amalgamation causes a fusion of cultures view to mutual respect and mutual adaptation of their respective cultures. Amalgamation is also present in Desa Bawang Tirto Mulyo and Desa Kahuripan Dalam. The findings in the field show that the people of both villages are mostly not too concerned with marriages that must occur among ethnic groups.
The majority of Javanese ethnic groups from all walks of life are not concerned about ethnic and religious differences.

They believe that all ethnicity and religion are good and about the choice of son-in-law, they can only suggest the best to the child, but for the last choice, the child is the one who determines. Generally all layers of society such as, public figures and ordinary people give up completely the choice to the child. However, in most religious leaders, the majority still require that their son wants to marry a different woman, especially a religion, then the woman must join their religion (the male side). While the ethnic Balinese also have the same thoughts, but the important note is, their son is forbidden to convert, because the son who later has the obligation to take care of the temple of ancestor worship. Especially in girls, they are given the freedom to marry anyone without a record. Such thinking according to Narwoko (2004) will obviously eliminate controversies when later arises a conflict. It is also in line with Debora's research (2013) that multicultural communities in West Pasaman make inter-ethnic crossbreeding (amalgamation) as one means of avoiding conflict, because with different ethnic marriages will be able to integrate interethnic this is due to the mutual respect and reluctance of the interethnic who do the marriage. 
Acculturation

Sumarsono (2012) reveals that ethnicity is a community group whose membership is based on the origin of the same offspring and is usually characterized by relatively similar physical features, such as color and hair type, nose shape, skin color and so on. Language can serve as one of the ethnic identity. Language is an integral part of a group's culture. Therefore, according to Nababan (1984) cultural elements such as rules, habits and way of life groups can be expressed through language. Language difference can cause difficulties and obstacles in the smoothness of communication in general. The way of selecting in a multilingual society is done by acculturation of language. Language differences also occur in Desa Bawang Tirto Mulyo and Desa Kahuripan Dalam. Indonesian is used both in formal and non-formal events. Javanese is chosen as the second language between Java and Bali to interact. According to ethnic Balinese speakers the selection of Javanese language as the second language used in everyday life because Java language is easy to understand. The majority of Balinese are able to communicate using Javanese language. In addition, the spread of Javanese ethnic communities almost in every corner of Indonesia makes the existence of Java language increased, so many other ethnic who are able to master the language.
Conversely, there are only small number of Javanese who can use the language Balinese language. According to Javanese speakers, Balinese language is difficult to understand, they understand passively Balinese language. This means that they only understand when they hear Balinese speak Balinese, but they are not much to speak in Balinese. The existence of variations of language usage according to Rokhman (2013) as a result of the speaker's need in communicating causes the linguistic situation in the society is quite complicated. So the people need the mastery of other ethnic languages for carrying out the communication. The people's way of choosing the language indicates that there is a tolerance in the lives of these two ethnic societies. Because, without any tolerance and openness, there would be no acculturation.

Another form of acculturation in Bawang Tirto Mulyo Village and Kahuripan Dalam Village is that they used different chef to serve between Balinese and Javanese guest. If the Balinese people have a "celebration", they will certainly invite relatives and friends they know from Balinese. Other form of tolerance and respect for the Balinese ethnic community in Kahuripan Village is that they will ask Javanese women to cook special invited guests from outside the Balinese, even other ethnic guest special cooking utensils were lent from 
Javanese. This is done to avoid the reluctance of other ethnic communities to eat the food presented because the dish of ethnic Balinese cuisine is identical to the pork and dog meat. When Balinese in Kahuripan Dalam village celebrate wedding celebration, they use a special chef for guests who come from outside the Balinese. However, it does not happen when Javanese community in Bawang Tirto Mulyo celebrate the special event because there no food which is religiously forbidden Balinese. The interaction between Java and Bali in Bawang Tirto Mulyo and Kahuripan Dalam villages has been long happening and therefore, there is mutual understanding between Balinese and Javanese people. They know each other 's way of religious customs and practices in which Bawang Titro Mulyo village is predominantly Muslim closely related to the issues of unclean food (especially pork). Today, ethnic Balinese people rarely treat their Muslim guests with their processed food when they celebrate special events. Usually they will provide other types of food / beverages that they may eat according to their religious view that are bought from food stall.

\section{CONCLUSIONS}

The dynamics of Javanese and Balinese intercultural life in Bawang Tirto Mulyo Village and Kahuripan Village Dalam run harmoniously. Opportunities to interact with each other are also wide open, this is because both ethnic groups have a high openness attitude towards other ethnic cultures. Their social relations no longer put forward the view that "my ethnicity is the best". The distinction between cultures and religions between the two ethnic groups is already visible. However, it no longer visible in terms of a social distance. Viewed from the social relations, their interdependence is manifested in the form of interconnected regardless to ethnic differences. This suggests that the same value of binding themselves to create social networks among them. Such social networks may occur because Javanese and Balinese have long involved in the interaction so that they know each other the customs.

The prolonged social contact between Javanese and Balinese in Bawang Tirto Mulyo and Kahuripan Dalam villages result in cooperation, assimilation, cultural acculturation of the two ethnic groups. The existence of amalgamation and being able to use other language (Java and or Bali) can reduce the conflict and raise an integration. Thus, social interaction will lead to integration, when people have confidence in the same value.

\section{REFERENCE}

Alfirdaus, Laila Kholid. Hiariej, Eric. Risakotta, Farsijana Adeney. (2014). Ethnic Relation Politics: Matrilinealitas and Ethnic 
Minorities of China in Padang, West Sumatra. Community Journal.Vol 6 (1):136-150. DOI: 10.15294 (https://doaj.org/article/a959e80e ac2048298d0ca159d5abfc69).access ed, on February 5, 2018. At 18. 22

Bungin, Burhan. (2012). Qualitative Research Data Analysis. PT. RajaGrafindo Persada.

Debora, Elly Kristin. Anggreta, Dian Kurnia, Yasin, Faishal. (2013). The Western Socio Cultural Multicultural Strategy Avoids Conflict. Journal of Social Sciences Mamangan. Vol 2(1):22-37 DOI 10.22202/mamangan.1367(https:// doaj.org/article/6ee2135c45af4762 b91b01fce3e102b9/). accessed, on February 5, 2018. At 19:28

Ma'hady, el-Muhaemin. (2004). Multiculturalism and Multicultural Education [A Preliminary Review], From:http://artikel.us/muhaemin604.html. accessed, October 27, 2007. At 16.00

Manan, Jmran. (1989). Socio-Cultural Basics Education, Jakarta: Project Development LPTK Department of Cultural Service, .

Nababan, P.W.J. (1984). Sociolinguistics. Jakarta. PT Gramedia
Narwoko, J. Dwi. Suyanto, Bagong. (2004). Sociology of Introduction and Applied Text. Jakarta. Kencana

Rokhman, Fathur. (2013). Sociolinguistics: A Language Learning Approach in Multicultural Societies Yogyakarta: Graha Ilmu.

Santosa, Iman. (2013). Sociology (The Key Concepts). Jakarta. PT Rajagrafindo Persada

Soekanto, Sarjono. (2015). Sociology An Introduction. Jakarta. PT. Raja Grafindo Pesada

Soemardjan, Selo and Soelaeman Sumardi, (1964). A Sociology Flower. Jakarta: Rajawali.

Sudjarwo. (2005). Social Interaction in Plural Society. Lampung. Publishing Center Research Institute of the University of Lampung

Sugiyono. (2013). Educational Research Methods. Bandung. Alfabeta.

Sujarweni, W. Wiratna. (2014). Research methodology. Yogyakarta. Pustaka Baru

Sumarsono. (2012). Sosiolinguistik. Yogyakarta: Pustaka Pelajar.

Zamroni. (1992). Introduction to Social Theory Development. Yogyakarta: Tiara Wacana

www.bps.go.id. accessed on July 7, 2017. At $13: 23$ 